Revista Educación

ISSN: 0379-7082

ISSN: 2215-2644

revedu@gmail.com

Universidad de Costa Rica

Costa Rica

\title{
Parent and Teacher Perceptions of Gradeless Assessment and its Relationship with Education Commodification: A Case Study
}

Pérez-Arredondo, Carolina; Bernales-Carrasco, Angela

Parent and Teacher Perceptions of Gradeless Assessment and its Relationship with Education Commodification: A Case Study

Revista Educación, vol. 46, núm. 1, 2022

Universidad de Costa Rica, Costa Rica

Disponible en: https://www.redalyc.org/articulo.oa?id=44068165031

DOI: https://doi.org/10.15517/revedu.v46i1.45575

\section{(c) $($ ) $\Theta \Theta$}

Esta obra está bajo una Licencia Creative Commons Atribución-NoComercial-SinDerivar 3.0 Internacional. 


\title{
Parent and Teacher Perceptions of Gradeless Assessment and its Relationship with Education Commodification: A Case Study
}

\author{
Las percepciones sobre el sistema de evaluación sin notas y su relación con la mercantilización de la educación: un \\ estudio de caso con docentes, padres y madres
}

Carolina Pérez-Arredondo

Universidad Andrés Bello, Chile

carolina.perez.a@unab.cl

https://orcid.org/0000-0002-1543-0797

\author{
Angela Bernales-Carrasco \\ Colegio Los Cipreses, Chile \\ angelaestefania@gmail.com \\ (iD) https://orcid.org/orcid.org/0000-0001-7104-3436
}

DOI: https://doi.org/10.15517/revedu.v46i1.45575 Redalyc: https://www.redalyc.org/articulo.oa? $\mathrm{id}=44068165031$

Recepción: 17 Febrero 2021

Aprobación: 11 Mayo 2021

\begin{abstract}
:
This qualitative study explores and identifies how parents and teachers address implementation of a gradeless system for teaching primary students English (EFL) and its effects on their academic development as experienced in a private school in Chile. Analysis of interviews and a focus group serves as a basis for obtaining insight about parent and teacher perceptions regarding changing to a gradeless system and how it poses challenges to academic development conceptions and practices. The study specifically focuses on how assessment is linked to the idea of success and the commodification of education through different conceptual metaphors. The data was analysed in light of a Discourse-Historical Approach (Reisigl \& Wodak, 2001, 2016) facilitated using corpus linguistics methods (concordance lines and frequency lists). Results indicate clear contradicting perspectives about implementing a gradeless system. On the one hand, parents and teachers alike are concerned about jeopardizing their children's future academic prospects by depriving them of numerical assessments since they believe that it positively fosters competition among students. On the other hand, parents and teachers are relieved at how embracing a gradeless system has improved their children's emotional wellbeing. Both stakeholders expressed the negative effects that numerical assessments had on their children and themselves since it led to student competition and, consequently, increased student stress, frustration, and anxiety. Overall, the study strengthens the need to conceptualize EFL education differently to prioritize academic and humanistic formation of individuals over standardized and marketed development.
\end{abstract}

KEYWORDs: Testing, Formative Evaluation, English, Standardization, Qualitative Analysis.

Palabras Clave: Test, Evaluación formativa, Inglés, Estandarización, Análisis cualitativo

\section{INTRODUCTION}

When addressing commodification of education, educators and policy makers tend to refer to the excessive importance attributed to the use and benefit of education as opposed to its intrinsic value and worth (Silbaugh, 2011). While the standardization of tests does contribute to this utilitarian understanding of education (see Rubin \& Kazanjian, 2011), grades and other sociocultural factors (i.e. what subjects are important, and which are not) also play key roles in the legitimation of commodification. In this context, learning English has become instrumental to the narrative of (global) success, and it plays a determining role in an individual's social dimension (Carmel, 2019; Nikolov, 2016). In South America, English remains the quintessential foreign language to teach at schools, largely supported by a neoliberal narrative of potential opportunities (Kamhi-Stein et al., 2017). Similarly, Chilean educational policies follow the same trend. 
Various governments have stressed the importance of learning English at schools, and have implemented different measures to achieve this goal (e.g., The English opens doors Program). These efforts, however, also target economic and aspirational goals (Byrd, 2013), which enhance the idea that English works "as a gatekeeper to positions of wealth and prestige" (Matear, 2008, p. 143). In addition, academic success, as reflected in school grades, heightens competition and stress among peers (Bernales-Carrasco, 2020). This is particularly true for young learners, whose parents strongly believe English can determine their children's opportunities of success and social mobility (Carmel, 2019), leading to parliamentary initiatives to tackle the consequences of such commodification by proposing the elimination of summative assessments for early education (Sepúlveda, 2018). Given this context, parent obsession with quantifiable measurements of their children's proficiency levels is hindered by implementation of a gradeless system which perceives assessment "as a means to improve (rather than prove) learning" (Inbar-Lourie \& Shohamy, 2009, p. 91).

This study aims to explore and identify how parents and teachers address implementation of a gradeless system for primary student English instruction and its impact on their children's academic development in a private school in Chile. Through the analysis of interviews and a focus group, parents, and teacher perceptions regarding switching to a gradeless system and its challenges to conceptions of their children's academic development are studied. There is a specific focus on how assessment is linked to the idea of success and commodification of education through conceptual metaphors and various discursive strategies proposed by the Discourse-Historical Approach (Reisigl \& Wodak, 2001, 2016).

The article is structured as follows. First, there is an overview of the main theoretical concepts that structure this study, namely, (English) language, grading, processes of commodification in education, and the implementation of gradeless systems. Second, the data and the methodology of the study are introduced and described. Finally, there is a thorough discussion of the main findings, followed by the main conclusions and further lines of investigation that stem from this study.

\section{THEORETICAL FRAMEWORK}

\section{(English) Language, Grading, and Commodification Process}

Language, understood as a social practice, is inherently intertwined with various aspects of social organization through material and symbolic resources (Bourdieu, 1991). Due to the advancement of capitalism, neoliberalism, and the tertiary sector, language has been consistently embedded in processes of commodification, in which its value is measured in "economic terms" (Heller \& Duchêne, 2016, p. 144). In this context, language stops being a source to enhance nationalism and national identity and becomes a source of profit through its marketization. For example, language cannot only become a signifier of authenticity in the tourism industry as it adds value to specific regions (Heller \& Duchêne, 2012, 2016), but it can also become an asset to compete in globalized job markets and networks (e.g. Allan, 2013; Zappettini, 2014). Consequently, Heller and Duchêne argue, "pride and profit are co-constitutive discursive tropes" (2012, p. 16) that enable the use of language as an economic asset in the construction of the nation-state and the neoliberal individual.

Given this background, English has emerged as a global means of communication, where people who learn English as a second or foreign language outnumber those who acquire English as their first (Mauranen, 2017). To respond to this global (and economic) demand, educational institutions have incorporated a business logic (e.g., Fairclough, 1992; Holborow, 2012; Martín \& del Percio, 2019) which foregrounds competition and efficiency, often equating quality with private funding (Wilkins, 2013). Hence, learning English becomes an indispensable skill to (economically) succeed in life (Cantón-Mayo \& Fernández-Díaz, 2018). For instance, schools which offer bilingual programs are regarded as more valuable because they 
advertise the advantages of learning English at early stages (Hidalgo \& Fernández-González, 2019). This neoliberal narrative particularly affects young learners. For many parents, English is regarded "as a valuable asset associated with prestige and economic welfare", which can determine someone's opportunities of success and social mobility (Carmel, 2019, p. 1). Consequently, many parents believe that the earlier they start learning, the better their chances to succeed (Carmel, 2019; Nikolov, 2016) despite strong evidence which proves otherwise (e.g., Rokita-Jaśkow \& Ellis, 2019).

This narrative of success associated to EFL acquisition is also widely shared by students themselves worldwide (Warriner, 2016; Xiong \& Yuan, 2018). In Korea, Park (2011) claims that the idea is that English allows people to have a better social status and be respected in their communities. Likewise, in Costa Rica, Ensser-Kananen et al. (2017) found that student motivation to learn a foreign language is considerably influenced by neoliberal dynamics, in which they truly believe English can advance their job and scholarship opportunities in the future. In Chile, Gómez and Pérez's (2015) study on high school student attitudes towards EFL demonstrated that $53 \%$ of the study participants believed English was important to their future. Similarly, according to Díaz and Morales (2015). even primary students believe that English is useful for their professional development. More importantly, these authors identified that this belief increases over time and combines the idea of professional success with that of social mobility.

At a national level, Chile has undertaken different measures to foster the teaching and learning of English at schools. For instance, English is compulsory from $5^{\text {th }}$ to $12^{\text {th }}$ grades throughout the school system, while optional for younger students. For optional content, the Ministry of Education has created specific materials to facilitate and standardize curriculums across public schools. Similarly, the English Opens Doors program - which is aligned to this neoliberal narrative- enhances a communicative approach to various activities with the goal of fostering student engagement with English while simultaneously highlighting its importance on student academic and professional development (Gómez \& Pérez, 2015). Nevertheless, all these public initiatives have yielded few results, given Chile's low scores on standardized EFL tests. In fact, these measures tend to widen the socio-economic gap among schools, prompting many parents to leave the public educational system for private and/or subsidized schools that offer compulsory English lessons starting in pre-school. As a result, students from a lower socioeconomic status lose motivation in learning a language they do not find useful, since opportunities to pursue higher education are scarce (Kormos \& Kiddle, 2013; Matear, 2008; Mizala \& Torche, 2012).

Similar to the role of English, grades are widely considered to be predictors of academic and professional success among the population. Elmore (2019) believes that assessment contributes to egitimation of neoliberal education narratives, since it allows the further classification of educational institutions and people alike. According to Elmore, assessments become institutionalized and instrumentalized, in that:

they carry society's formal definition, literally, of "what counts" and consequently "who counts." Over time, these definitions congeal into accepted social judgments - "good schools," "bad schools," "smart students," "dull students," "gifted students," "needy students," and ultimately to distinguish those who "deserve" to succeed, from those who don't, the working definition of "merit" (p. 329).

Grading is constructed as an objective measurement of a student's learning process and an indicator of academic capability and future potential (Heflebower et al., 2014). Standardized tests, for example, fulfill this objective and foster comparison among cities, regions, and even countries regardless of socio-economic and cultural factors, holding teachers and schools accountable for students' scores (Silbaugh, 2011). These preconceptions about grading can create conflicting dynamics among students who might not only equate learning with good grades, but might also strive for high scores instead of their academic and human development (Wright, 2012). This asymmetrical relation can promote several malpractices among students and teachers such as cheating, inflating scores, less collaboration in the classroom, and the neglection of more disadvantaged students (Morgan, 2016). In fact, even though evidence shows that a lettering and numerical grading systems have negative impacts on students motivation and achievement (e.g., Kohn, 
1999, 2013; McMorran et al. 2017; McMorran \& Ragupathi, 2019; O’Connor \& Lessing, 2017; White \& Fantone, 2010), "current educational models have privileged reproductive, instrumental, and memorydriven assessment practices” (Rodríguez \& Jarpa, 2015, p. 62).

In Chile, grades play a fundamental role in a student's possibilities to be accepted by a "good" university. Student grade point average (henceforth NEM) is included as a percentage within the final PSU[1] score as evidence of student academic performance. While, originally, a well-intentioned reform to the university admission test, and in line with what has been discussed thus far, NEM's ability to actually represent an objective reflection of students' academic performance has been widely questioned (Contreras et al., 2009; Prieto \& Contreras, 2008). For instance, Rodríguez and Jarpa (2015)'s study found that NEM is not a predictor of PSU high scores, a difference that is heightened in the lower socio-economic spectrum. This evidences that the importance attributed to grades can create vicious circles within students' learning processes, where students' motivations are corrupted by the need of achieving good grades; they steer their learning process towards the achievement of high scores, causing increased stress and frustration and negatively affecting their academic and human development.

In this context, the implementation of an assessment system that does not rely on numerical measurements can create a haven for students' metal wellbeing and academic development. The following section explores what gradeless assessment is and how it has been implemented in different educational levels.

\section{Going Gradeless: An Overview}

The implementation of a gradeless system challenges the pervasive nature of neoliberal narratives within the educational sector, as the focus returns to students and their buman development. Gradeless assessment, that is, "assessment without letters or numerical grades such as pass/fail systems and narrative evaluations" (McMorran et al., 2017, p. 361), aims to help students adjust to the academic pressure of education, encourage more cooperation and less competition, and improve overall students' well-being.

Evidence on the effects of the implementation of a gradeless assessment on students' anxiety and stress levels has usually revolved around higher education. For instance, Bloodgood et al. (2009) found that gradeless learning reduced anxiety and depression while it increased positive well-being and vitality. Similarly, Mogali et al. found that formative assessment was in general "less stressful than using summative ones because of the friendly environment that group evaluation provides to students" (2020, p. 587; see also O'Keeffe et al., 2018). O'Connor and Lessing (2017) also found that the absence of numerical assessment enhanced learners' intrinsic motivation, the establishment of meaningful relationships between teachers and students, and promoted knowing each learner as an individual person.

Nevertheless, little attention has been given to the role of gradeless assessment in early education. There seems to be only one study carried out in the Chilean context that considered classroom observations to identify the effects of such an assessment in young learners. In her study on the impact of gradeless assessment on first graders' oral skills in their EFL class, Bernales-Carrasco (2020) found that students were, in fact, more motivated and less frustrated in their EFL speaking assessment. However, classroom observations evidenced that there is also a demotivation on gifted students, who showed signs of boredom.

Replacing grades by other kinds of assessment could be difficult in a culture where students' achievement is constantly rewarded by parents and teachers. In fact, "school administrators should be prepared to respond to parental concerns about the prospect of edging away from grades and to assure them that alternative assessment provides a far better view" (Kohn, 1999, p. 32). In the same way, professional teachers who notice that grading affects their students' learning continue using the same grade-oriented approach. They argue that children will face this system of evaluation later at middle school, high school, and at university so students might suffer a hard change anyway. On this, Kohn highlights that "the important point here is whether those difficulties are seen as problems to be solved or as excuses to perpetuate the status quo" (1999, p. 3). The 
author believes that the cultural conditions needed to innovate and incorporate this kind of assessment do not exist yet. There is a need for a combination of actors such as school administrators, parents, educators, and students from a particular educational community that need to be informed and prepared for that.

\section{DATA AND METHODOLOGY}

This research design follows an intrinsic case study (Stake, 2005), where one of the first private schools to implement a gradeless system in the region was selected. Due to the lack of schools applying this kind of assessment, an intrinsic case study allowed us to explore EFL teachers and parents' perceptions and reactions to going gradeless. The school, located in a southern capital of Chile, implemented this system to its three Year 1 classes in 2019, thus excluding older students who have already been familiarized with grades. First graders have six hours of English-only lessons a week, with weekly formative assessments evaluating oral and listening skills. To this end, teachers follow a scoring rubric[2] that is never accessible to students, but it is shared with parents through performance reports. Their performance also includes an estimated scoring scale, ranging from excellent (which would correspond to the highest score in the traditional Chilean educational system: 7.0) to needs improvement (which would reflect a traditional failing score: from 1,0-3,9). Both the reports and estimations are turned into a final grade at the end of the year that teachers later upload to the school platform, as required by the Ministry of Education.

Considering how the implementation of a gradeless system was executed at this school, the sampling criteria consisted in approaching all the EFL teachers in charge of Year 1 students (two teachers) and Year 1' parents. In the case of the EFL teachers, they were thoroughly informed about the objectives of the study and were asked to sign an informed consent allowing the researchers to interview them. In the case of the parents, the researchers distributed a summary of the objectives, which included the authors' contact information, with the assistance of the participating EFL teachers. As a result, six parents from the three classes approached the researchers to participate in the study and were asked to signed consent forms as well.

The data was collected through two different methods: semi-structured interviews (to EFL teachers) and a focus group (to the children's parents). On the one hand, semi-structured interviews allowed for more flexibility when interacting with the teachers while simultaneously allowing them to elaborate on their particular points of interest through the questions (Denscombe, 2020). The two EFL teachers responsible for Year 1 were interviewed in late September 2019 and asked different questions about the implementation of this gradeless system[3]. The interviews were carried out in Spanish, recorded, and transcribed for their analysis. On the other hand, the realization of a focus group can foster debate and fuel interaction among participants on a particular topic (Krzyżanowski, 2008). In this study, the parents' focus group, which lasted 60 minutes approximately, took place in early October 2019, and two children's books were raffled at the end to thank them for their participation. While there was a second focus group with more parents scheduled on the following week, the State of emergency declared in Chile on 18 October 2019 cancelled the remaining school year (Bartlett, 2018), which prevented the collection of more data. Nevertheless, the sample was representative of all Year 1 classes at that school, the interactions were fruitful, and the interviews with the EFL teachers were also used to triangulate results.

The data were analysed following the principles proposed by Critical Discourse Studies (henceforth, CDS), a research paradigm (Wodak \& Mayer, 2016) whose main objective is to study how "social-power abuse and inequality are enacted, reproduced, legitimated, and resisted” in society (van Dijk, 2015, p. 466). While there is extensive literature on the theoretical and methodological scope of CDS (e.g. Flowerdew \& Richardson, 2018; Wodak \& Meyer, 2016), the interest of CDS in education is still relatively new (Rogers et al., 2016). This study falls under the tradition of CDS studies on neoliberal discourses in education, namely, the commodification of grades and English language learning (e.g., Fairclough, 1992). 
This study follows the Discourse-Historical Approach (henceforth DHA), a context-sensitive methodological framework proposed by Reisigl and Wodak $(2001,2016)$. The DHA seeks to unveil the dialogical inconsistencies and contradictions in the construction and representation of social and discursive practices to exercise social change (Reisigl \& Wodak, 2001). The approach explores specific fields of actions where discourse topics emerge. In this study, EFL education, assessment, and their relations with neoliberal discourses are explored. Discourse, in this sense, is regarded as: "a complex bundle of simultaneous and sequential interrelated linguistic acts that manifest themselves within and across the social fields of action as thematically interrelated semiotic (...) tokens (...) that belong to specific semiotic types, i.e., genres" (Reisigl \& Wodak, 2001, p. 36).

The analysis consists of the identification of five discursive strategies in the oral texts collected from the focus group to students' parents and the semi-structured interviews to the EFL teachers. These strategies include various linguistic resources used to describe social stakeholders (i.e., referential strategies) and (their) social actions (i.e., predicational strategies) as well as the arguments used to support such descriptions (i.e., argumentation strategies). The latter aims to persuade through obligatory, culturally shared premises (i.e., topoi) or argumentative fallacies to support and/or challenge assumptions about people's reality or communities. The approach also considers how people (strategically) exaggerate or downplay certain constructions (i.e., intensifying and mitigation strategies) to frame the overall argument from specific viewpoints (i.e., perspectivation strategies). While it is impossible to provide a comprehensive description of each of these strategies due to space constraints (see Reisigl \& Wodak, 2001 for more details), short definitions and explanations of these strategies are provided in the texts in the results section instead.

Finally, the manual analysis was assisted with corpus methods to discourse studies (Baker, 2006). In particular, frequency lists and concordance lines were used to identify the relevant social stakeholders and actions discussed in the data. Frequency lists are usually disregarded as a mere quantification of words in a corpus. However, Baker argues, they can expose "something about [people's] intentions, whether conscious or not" (2006, p. 48). The quantification of words alone does not yield interesting results, nor it facilitates the identification of discourses in a text. For this purpose, concordance lines were also used to complement the analysis of how the most common words in the corpus are actually used by the participants. Concordances refer to "a list of all the occurrences of a particular search term (...), presented within the context that they occur in; usually a few words to the left and right of the search term" (Baker, 2006, p. 71). By exploring the most frequent words and their co-text, it was possible to focus on the emerging discourses used by the social stakeholders interviewed in relation to the implementation of a gradeless system and the impact it has had in the academic development of their children/students.

The results of this methodological design are described in the following section.

\section{RESULTS}

The analysis showed very specific ways of identifying the effects the implementation of a gradeless system has had on specific social stakeholders (i.e., children, parents, and teachers) and social actions (i.e., assessment and learning). Table 1 shows the 10 most common content words of both the interviews and the focus groups: 
TABLE 1

Corpus-Based Frequency Words.

\begin{tabular}{|c|c|c|c|}
\hline Freq & Word & Freq & Word \\
\hline 40 & Niños [children] & 24 & Tema [issue] \\
\hline 35 & Evaluación [assessment] & 22 & Metodologia [methodology] \\
\hline 34 & Uno [one] & 21 & Niño [child] \\
\hline 33 & Inglés [English] & 18 & Nota [grade] \\
\hline 24 & Notas [grades] & 18 & Proceso [process] \\
\hline
\end{tabular}

Source: Prepared by the authors.

Table 1 shows a clear focus on children and the effects of assessment, whether this is gradeless or a more traditional, numerical one. While having this frequency is useful, these results remain unsurprising. It was expected to get parents and teachers to discuss these issues, particularly in relation to English and their children. A closer analysis, however, indicated distinctive semantic fields that emerged from the discussion and sheds light on teacher and parent attitudes and involvement towards EFL teaching/learning and grading.

A concordance analysis helped identify specific conceptual metaphors (Lakoff \& Johnson, 1980) that framed teachers interviews and a parent discussion group. According to Reisigl and Wodak (2001) through metaphors, speaker involvement, was identified which "aim both at expressing the speakers' inner states, attitudes and feelings or degrees of emotional interest and engagement and at emotionally and cognitively engaging the hearers in the discourse" (p. 82). For these participants, metaphors led to identifying specific frames that structure their interaction and relationships with their students/children regarding the long-lasting impact of non-numerical assessments, particularly for EFL. It is worth noting that these metaphors illustrate the pervasive nature of neoliberal practices in the educational system despite such overt condemnation by teachers and parents. The aforementioned metaphors are explored in the following sections.

Learning (english) is a competition

A common topic noted among participants was that of competition. Grades were identified as the source of competition and contributed to a detrimental learning atmosphere where the educational system and parents, alike, are to blame. Although teachers maintained that grades serve as a source of motivation for their students, they can also deter students:

"Well, children in Year 1 do not know what a grade is, so since they don't know that reality, they don't know what they are doing, don't know what they are missing on, so as they don't know, don't know, I motivate them with games, for them the English class is a game (Teacher 1, personal communication, September 30, 2019)".

The positive notion of grades also consists in its value as an asset used to enrich student academic experience. These linguistic attributes implicitly evaluate grades as a must in the classroom (Reisigl \& Wodak, 2001), comparable to engaging students in active and collaborative participation. This positive evaluation is enhanced by the idea of these children's ignorance due to their young age. There is a constant repetition of not knowing what they are doing in the classroom (when these teachers evaluate them) so the teacher resorts to back up strategies to help her motivate and engage with these young learners (i.e., learning (english) is a game). Moreover, it is evident these teachers consider grades as an indispensable part of their teaching practices. Teacher 2, for instance, claims she needed to resort to Plan $B$ to motivate the students in the absence of grades. This understanding of the role of grades has been documented in studies on the benefits of formal assessment by researchers such as Box et al. (2015) and Jessop and Hughes (2018).

Yet, grades are also useful for ranking students, both in the classroom and in life. This is particularly true for Teacher 2 , in the example. The teacher casually mentions the need to differentiate advanced and slow 
students to facilitate gradeless assessment procedures, conduct assessments more rapidly and grant struggling students more time. However, she argues that:

[Not having grades] can be disastrous for those who with issues managing frustration, because life measures and standardizes us. We are adults who, to apply for a job, must go through a filter, for anything we go through a filter. So, what is going to happen to these kids? that, maybe, they do not have this awareness of their weaknesses and strengths (Teacher 2, personal communication, September 30, 2019).

The teacher overtly criticizes gradeless assessments by foregrounding the role of emotions in education. From her understanding, grades help students learn and overcome challenges. Grades serve as motivators. Interestingly, however, she creates a parallel with the real world though the conceptual metaphor education is a market. People's achievements are measured and standardized, in which grades are evidence of that process. In the end, this teacher argues, all people are sorted through a utilitarian filter, where some are useful to the job market and others are not (see also Elmore, 2019). The academic and more humanitarian development is backgrounded in exchange for a more utilitarian understanding of education, where English plays an important role.

In the same vein, parents also explicitly highlight how they, inadvertently, transfer this competition to their children. Take the following extract as an example:

"I think that sometimes one, as a parent, makes the mistake of asking 'how did X do, the smart one?' I think that in other school subjects such as Language is more notorious, because some of them are already reading, and they are not, and they tell us 'Mom, you know what? Juanito is reading super fast' (Parent 2, personal communication, October 02, 2019)”.

The extract illustrates a parent's constant surveillance on the academic performance of their children and their classmates. Learning and achievement in this context serve to categorize their children in relation to others: the better they do at school, the better they are when compared to others (relational identification).

This categorization seems to be of special concern to parents, which children incorporate as their own. Consequently, learning becomes an instance in which to show their worth despite the negative effects it can have on their wellbeing. On this, Parent 3 elaborates:

"Based on my experiences with my older kids, I realized that I pushed them too hard, asking them 'what grade did you get? Why?' because they have always excelled academically, since Year 1. But the youngest one, I already have a new perspective because in the end I triggered that preoccupation of 'how did you get a 5.0?' '...and what grade did X's daughter?' So, when my oldest daughter arrived [from school], I triggered that fear of telling me, it was I! we both fell for that. But oh well, that is over now (personal communication, October 02, 2019)".

While fear is nominalized as a concept to express the effects of their pressure in their children, the concept remains rather vague enough to create a dichotomy of us vs them (i.e., my child versus somebody else's child). The effects of this fear are shared by other parents who only agree with this intervention. It could be safely assumed that this fear is used as a reference to the negative reactions that children experiment during evaluations, even at such a young age (see next section). In addition, this can also be contextualized as a fear of failure, and a fear to disappoint their parents, who are heavily invested in the academic development of their children to give them the tools for their future. This is also seen in other instances were these parents show how much they invest in their children's education. For instance, a parent shared they had a private tutor to help their child in Year 1 with English acquisition (Parent 4) while another has installed an app to foster vocabulary learning (Parent 5 ).

Unequivocally, parents uphold the idea that English is necessary to the future success of their children. Parent 5 argues that teaching English is necessary in Higher Education, as evidenced by their oldest son's experience at university: "English is very necessary, and the younger they are, even better, at least what I see is not a matter of stress" (personal communication, October 02, 2019). It is interesting to nothe that the younger the better theme is a common discourse used by parents to justify the need for their children to learn 
English despite stress and/or work overload (Carmel, 2019). Similar to the idea shared by the teachers, the need to stand out from the group is also mentioned by these parents, who believe that the more skills children learn, the better their chances to succeed in life:

Parent 5: "In the end you do realize when you work, you face a very competitive scenario. Before, it was enough to just go to university and that was great. Nowadays, it's 'go to university, get a postgraduate degree, a $\mathrm{PhD}$, and we are always looking for endless things to be on top'".

Parent 6: "in the end, what we are preparing them for... ".

Parent 5: "Exactly! And how do we prepare them for that? That's the point. Because it is not like we can lock them in a bubble, right? (Personal communication, October 02, 2019)".

These interactions build on the conceptual metaphor of "life as a race", where people are supposed to be in constant movement to win and succeed in life. Nevertheless, it is also apparent to these participants that this constant pressure to win, and be the best, also impacts these children's wellbeing negatively, which leads to the next conceptual metaphor.

Summative assessment is torture

While parents and teachers contend that grades are in fact beneficial for their children and students, grades are also systematically identified as a source of pain and suffering to all the social actors involved in the learning process. Parents explicitly mention how grading affects their children's wellbeing and how happy they are that their children are much less stressed when compared to their older children who have been numerically assessed all their lives. Some of them felt that grades were a punishment, drawing on the same categorization mentioned in the previous section (i.e., a dichotomy of good vs bad students). For instance, Parent 1 claims: "I believe he knows when he is being evaluated but he doesn't feel it is a punishment anymore, which I like" (personal communication, October 02, 2019), which leads to less "suffering" (Parent 2, personal communication, October 02, 2019). This paves the way for other parents to join in the conversation and share their own experiences as students:

and they published it, you could see it. And they used the students' list: Fulano, X, Mengano, another one. Or they handed out grades in decreasing order. And when they were at around 4.0, ohhh I was screwed. And they compare each other! They compare! It was awful! (Parent 5, personal communication, October 02, 2019).

From these interactions, it is evident the experience of being assessed is constructed as a traumatic one (predicational, intensifying, and perspectivation strategies). This fear of being compared, of being punished for not meeting specific performance criteria and their parents' expectations, and of public humiliation contribute to the construction of the conceptual metaphor assessment is torture. Their own experiences as students work as a projection of their children's wellbeing, which justifies their approval of the implementation of a gradeless assessment system.

Because of these negative effects on children, teachers also felt being tortured into causing this pain to their students. Teacher 1, for instance, explicitly mentioned the word torture when it came to describe the role of grading students in primary school (predicational strategies): "For me, it was like torture to orally assess these little ones [in English]" (Teacher 1, personal communication, September 30, 2019). Similarly, Teacher 2 highlighted the pressure she was under to comply with these grading strategies, even though they negatively affected students. Interestingly, who or what forces this teacher into this practice remains suppressed from her account. In this sense, both teachers felt obliged to formally and numerically assess these young learners to avoid a worse end. In this sense, they feel relieved by having a gradeless system that prevents these reactions in children: "the children have lowered their affective filter and, truth be told, you do not see these nervous kids anymore, those who clutch their hands, that suffer, that are frustrated, that cry" (Teacher 1, personal communication, September 30, 2019).

Parents and teachers are happy their children/students do not have to experience grades at such an early age, but they are simultaneously concerned of how this will affect their chances in the future. In other words, 
there is a clear contradiction between what and how they expect their children and students to learn, and how this process makes them feel. Ultimately, however, both parents and teachers believe that the implementation of a gradeless system will not have a lasting positive effect in their children and students because they will lack the resources to survive in the real world. Take the following extract as an example:

He [their child] tells me he wants to go to Paris. So, I explain to him that each country speaks different language, but mostly English. So, I say, but I don't speak English at all, so if we are going to go, then you must be my translator. He laughs at it, but it seems that it does the trick to motivate him (Parent 3, personal communication, October 02, 2019).

There is a utilitarian understanding of English, in which the language becomes an asset to travel. These predicational strategies mirror a discourse of globalization and international aspirations in which learning English is key (Carmel, 2019). From her perspective, the fact she does not know the language serves to motivate her child into learning, focusing on a goal rather than the learning process itself.

As evidenced by the discussion, the study has shown some contradictions in relation to how parents and teachers perceive the implementation of a gradeless system influenced by a discourse of marketization of education. These contradictions are summarized in Figure 1.

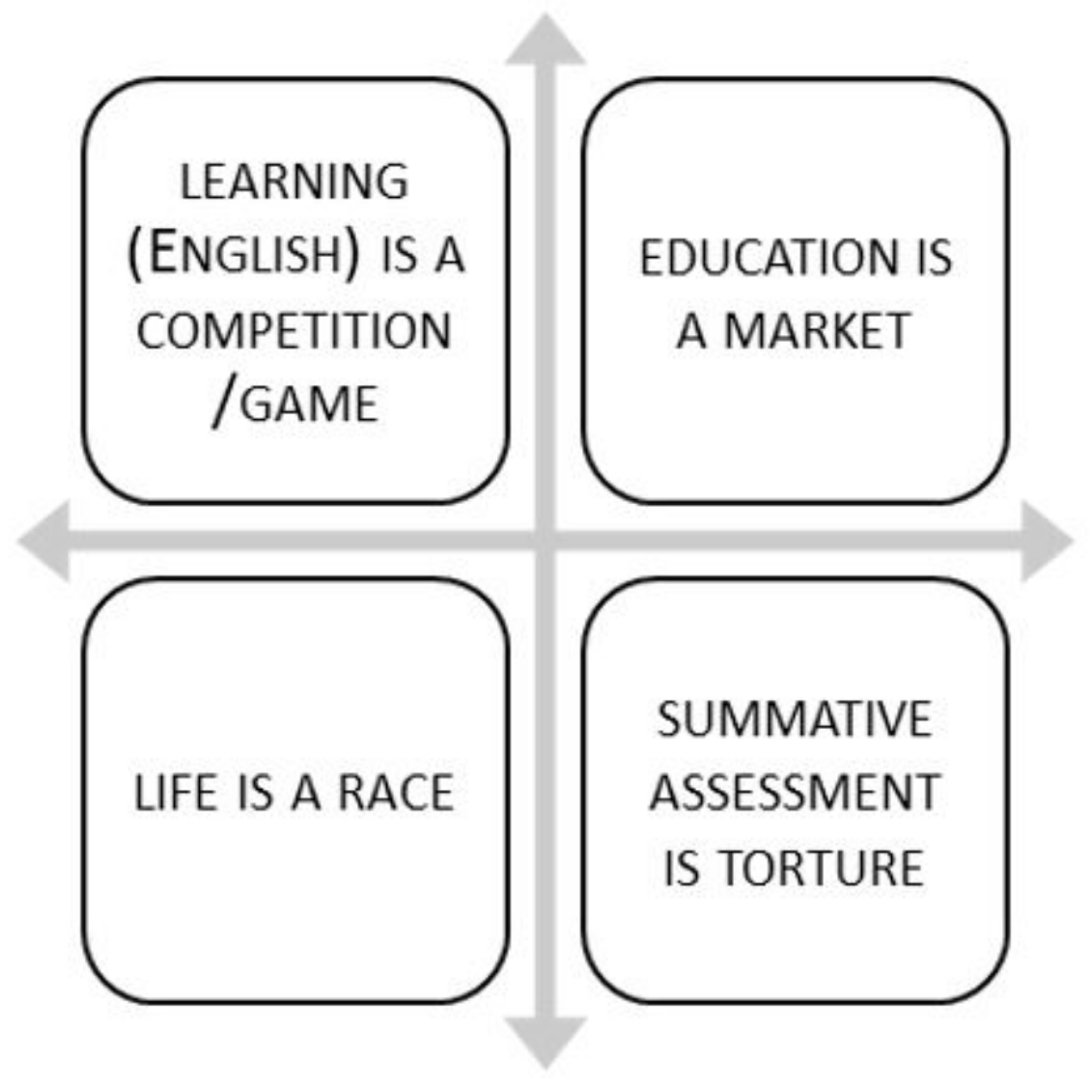

FIGURE 1

Conceptual Metaphors and Education as a Commodity Source: Prepared by the authors.

The basis for these conceptual metaphors seems to be the understanding of life as a race, which inevitably leads to the winners vs losers dichotomy. In an extremely competitive and marketized environment where knowing English is a distinguishable and profitable asset, learning also becomes a competition. Hence, students are inadvertently encouraged by their parents and teachers to engage in this dichotomy, in which they are praised if they excel, or looked down on if they fail. However, parents and teachers also acknowledge 
how tortuous and detrimental this understanding is when extrapolated to the educational context. While they are happy a gradeless assessment will allow their children to protect their mental wellbeing and humanistic development, they also see the attempt as futile. From their perspective, these children will eventually know how things work, and enter the rat race without the allegedly necessary toughness they could have developed at school.

\section{CONCLUSIONS}

This study explores parent and teacher perception towards implementation of a gradeless system and how it challenges conceptions and practices for supporting their children's academic development. Two clear patterns were evidenced regarding discursive construction of grades and the role of English in their children's education. First, numerical assessment not only stirs the competition among peers, but also does so among parents, who transmit their frustrations and anxieties onto their children, who, in turn, become stressed during summative assessmens. This constant competitive cycle is further heightened by parental beliefs that English is fundamental to safeguarding their children's future academic prospects. Grades are conceived as useful motivators for these young EFL learners, thus, correlating with previous studies (Box et al., 2015; Carmel, 2019; Jessop \& Hughes, 2018). More importantly, this also draw on the idea of education as a commodity where students become useful or disposable depending on how they are measured by their educational system (Elmore, 2019; Rubin \& Kazanjian, 2011), a concern shared by both parents and teachers alike. Second, parents, students and teachers, alike have stated feeling and overall sense of relief in using a gradeless system. Numerical assessment is explicitly compared to torture by parents and teachers, who reminisce on their own negative and traumatic experiences as students. They, clearly, notice a reduction of stress and frustration on these students, which was also highlighted in classroom observations of these group of students (Bernales-Carrasco, 2020). Thus, there is contradicting co-existence between commodification of knowledge and humanistic and academic development. In other words, while both parents and teachers attempt to protect young learners from competing against each other and being categorized, they still worry about the real world and the negative impact on their emotional resilience.

Research findings suggest different courses of action to adopt at both a macro and micro level. At the macro-level, the results posit specific challenges to current educational policies on EFL learning and teaching. First, a technocratic-oriented narrative to learning English as a Foreign Language seems to enhance inequalities in general (and the socio-economic gap in the Chilean educational system in particular). Second, emphasis on professional development and future success might promote malpractices at an administrative level and discourage teachers struggling with foreign language instruction

with limited resources and/or in less-than-ideal contexts. At a micro-level, grades seem to negatively affect students' mental wellbeing, which in turn can promote malpractices within the classroom to meet their teachers and/or parents' expectations. Consequently, teachers might need to find other ways to motivate students through play and interaction so students and parents can focus on the learning process rather than a (measurable) outcome.

Similarly, based on the results of this study, there is a need to conceptualize (EFL) education differently to prioritize the academic and humanistic development of individuals over standardized and marketed development. In Chile, implementation of a gradeless assessment methodology openly challenges the core of education itself and its standardization practices, which would result in fewere schools to conduct studies with a broader scope of participants. However, more educational institutions are considering similar assessment strategies, particularly outside the metropolitan region, due to constant protests against the quality of public education in the country. Hence, a second phase of this study consists in analyzing other schools that have attempted implementation of a similar methodology with a longitudinal study to explore and track potential effects among students, teachers, and parents alike. 


\section{REFERENCES}

Allan, K. (2013). Skilling the self: The communicability of immigrants as flexible labour. In A. Duchêne, M. Moyer \& C. Roberts (Eds.), Language, migration and social inequalities: A critical sociolinguistic perspective on institutions and work, (pp. 56-78). Multilingual Matters.

Baker, P. (2006). Using corpora in discourse analysis. Continuum.

Bartlett, J. (2018). Chile protests: State of emergency declared in Santiago as violence escalates. The Guardian. https://www.theguardian.com/world/2019/oct/19/chile-protests-state-of-emergency-declared-in-s antiago-as-violence-escalates

Bernales-Carrasco, A. (2020). Impact of a gradeless learning assessment in English oral tests: A case study of three elementary first grade' school classes from a private school in Rancagua, Chile [MA dissertation]. Universidad Andres Bello.

Bloodgood, R. A., Short, J. G., Jackson, J. M. \& Martindale, J. R. (2009). A change to pass/fail grading in the first two years at one medical school results in improved psychological well-being. Academic Medicine, 84(5), 655-662. https://doi.org/10.1097/ACM.0b013e31819f6d78

Bourdieu, P. (1991). Language and symbolic power. Polity Press.

Box, C., Skoog, G. \& Dabbs, J. M. (2015). A case study of teacher personal practice assessment theories and complexities of implementing formative assessment. American Educational Research Journal, 52(5), 956-983. h ttps://doi.org/10.3102/0002831215587754

Byrd, K. (2013). Reactions to English language learning in Chile as a means for personal and national development [MA dissertation]. University of San Francisco. https://repository.usfca.edu/thes/57/

Cantón-Mayo, I. \& Fernández-Díaz, J. (2018). Estado de la cuestión en Revistas de Educación sobre el éxito profesional. International Journal of Educational Research and Innovation, 10, 64-90. https://www.upo.es/rev istas/index.php/IJERI/article/view/3457

Carmel, R. (2019). Parents' discourse on English for young learners. Language Teaching Research, 00(0)1-19. https: //doi.org/10.1177/1362168819877080

Contreras, D., Gallegos, S. \& Meneses, F. (2009). Determinantes de desempeño universitario: ¿Importa la habilidad relativa? Calidad en la Educación, 30, 18-48. http://dx.doi.org/10.31619/caledu.n30.172

Denscombe, M. (2020). The good researcher guide: For small-scale social research projects (4th ed.). Open University Press.

Díaz, C. \& Morales, H. (2015). Creencias de estudiantes de primaria sobre el aprendizaje del inglés en un establecimiento educacional chileno. Revista Electrónica Actualidades Investigativas en Educación, 15(1), 1-20. https://revistas.ucr.ac.cr/index.php/aie/article/view/17730

Elmore, R. (2019). The future of learning and the future of assessment. ECNU Review of Education, 2(3), 328-341. https://doi.org/10.1177/2096531119878962

Ennser-Kananen, J., Escobar, C. F. \& Bigelow, M. (2017). “It's Practically a Must": Neoliberal Reasons for Foreign Language Learning. International Journal of Society, Culture and Language, 5(1), 15-28. http://www.ijscl.net /article_22788.html

Fairclough, N. (1992). Discourse and social change. Polity Press.

Flowerdew, J. \& Richardson, J. E. (2018). The Routledge handbook of critical discourse studies. Routledge.

Gómez, E. \& Pérez, S. (2015). Chilean 12th graders' attitudes towards English as a foreign language. Colombian Applied Linguistics Journal, 17(2), 313-324. http://dx.doi.org/10.14483/udistrital.jour.calj.2015.2.a10

Guskey, T. R. \& Marzano, R. J. (2001). Scoring rubrics in the classroom: Using performance criteria for assessing and improving student performance. Corwin Press, Inc.

Heflebower, T., Hoegh, J. K. \& Warrick, P. (2014). A school leader's guide to standards-based grading. Marzano Research Laboratory. 
Heller, M. \& Duchêne, A. (2012). Pride and profit: Changing discourses of language, capital and nation-state. In A. Duchêne \& M. Heller (Eds.), Language in late capitalism: Pride and profit (pp. 1-21). Routledge.

Heller, M. \& Duchêne, A. (2016). Treating language as an economic resource: Discourse, data and debate. In N. Coupland (Ed.), Sociolinguistics: Theoretical debates (pp. 139-156). Cambridge University Press.

Hidalgo, E. \& Fernández-González, N. (2019). Framing "choice" in language education: The case of freedom in constructing inequality. In L. Martin \& A. del Percio (Eds.), Language and Neoliberal Governmentality (pp. 6990). Routledge.

Holborow, M. (2012). What is neoliberalism? Discourse, ideology and the real world. In D. Block, J. Gray \& M. Holborow (Eds.), Neoliberalism and Applied Linguistics (pp. 14-32). Routledge.

Inbar-Lourie, O. \& Shohamy, E. (2009). Assessing young language learners: What is the construct? In M. Nikolov (Ed.), The Age Factor and Early Language Learning (pp. 83-96). De Gruyter Mouton.

Jessop, T. \& Hughes, G. (2018). Beyond winners and losers in assessment and feedback. In J. P. Davies \& N. Pachler (Eds.), Teaching and Learning in Higher Education (pp. 64-84). IOE Press.

Kamhi-Stein, L., Diaz Maggioli, G. \& Oliveira, L. (2017). English Language Teaching in South America: Policy, preparation and practices. Multilingual Matters.

Kohn, A. (1999). From degrading to de-grading. High School Magazine, 6(5), 38-43.

Kohn, A. (2013). The case against grades. Educational Leadership, 69(3), 28-33. https://www.jstor.org/stable/4298 2088

Kormos, J. \& Kiddle, T. (2013). The role of socio-economic factors in motivation to learn English as a foreign language: The case of Chile. System, 41(2), 399-412. https://doi.org/10.1016/j.system.2013.03.006

Krzyżanowski, M. (2008). Analysing focus group discussions. In R. Wodak \& M. Krzyżanowski (Eds.), Qualitative Discourse Analysis for the Social Sciences (pp. 162-181). Palgrave Macmillan.

Lakoff, G. \& Johnson, M. (1980). Metaphors we live by. The University of Chicago Press.

Martín, L. \& del Percio, A. (2019). Neoliberalism, language, and governmentality. In L. Martín Rojo \& A. del Percio (Eds.), Language and Neoliberal Governmentality (pp. 1-26). Routledge.

Matear, A. (2008). English language learning and education policy in Chile: Can English really open doors for all? Asia Pacific Journal of Education, 28(2), 131-147. https://doi.org/10.1080/02188790802036679

Mauranen, A. K. (2017). Conceptualising ELF. In J. Jenkins, W. Baker \& M. Dewey (Eds.), The Handbook of English as a Lingua Franca (pp. 7-24). Routledge.

McMorran, C. \& Ragupathi, K. (2019). The promise and pitfalls of gradeless learning: Responses to an alternative approach to grading. Journal of Further and Higher Education, 44(7), 925-938. https://doi.org/10.1080/030 9877X.2019.1619073

McMorran, C., Ragupathi, K. \& Luo, S. (2017). Assessment and learning without grades? Motivations and concerns with implementing gradeless learning in higher education. Assessment \& Evaluation in Higher Education, 42(3), 361-377. https://doi.org/10.1080/02602938.2015.1114584

Mizala, A. \& Torche, F. (2012). Bringing the school back in: The stratification of educational achievement in the Chilean voucher system. International Journal of Educational Development, 32(1), 132-144. https://doi.org/1 0.1016/j.ijedudev.2010.09.004

Mogali, S. R., Rotgans, J. I., Rosby, L., Ferenczi, M. A. \& Beer, N. L. (2020). Summative and formative style anatomy practical examinations: Do they have impact on students' performance and drive for learning? Anatomical Sciences Education, 13(5), 581-590. https://doi.org/10.1002/ase.1931

Morgan, H. (2016). Relying on high-stakes standardized tests to evaluate schools and teachers: A bad idea. The Clearing House: A Journal of Educational Strategies, Issues and Ideas, 89(2), 67-72. https://doi.org/10.1080/00098655 .2016 .1156628

Nikolov, M. (2016). Trends, issues, and challenges in assessing young language learners. In M. Nikolov (Ed.), Assessing young learners of English: Global and local perspectives (pp. 1-18). Springer. 
O'Connor, J. S. \& Lessing, A. D. (2017). What we talk about when we don't talk about grades. Schools, 14(2), 303318. https://www.journals.uchicago.edu/doi/abs/10.1086/693793

O'Keeffe, M., Gormley, C. \& Ferguson, P. (2018). Moving the focus from grades to feedback: a case study of pass/fail marking. Practitioner Research in Higher Education, 11(1), 70-79. https://eric.ed.gov/?id=EJ1180128

Park, J.S-Y. (2011). The promise of English: linguistic capital and the neoliberal worker in the South Korean job market. International Journal of Bilingual Education and Bilingualism, 14(4), 443-455. https://doi.org/10.10 $80 / 13670050.2011 .573067$

Prieto, M. \& Contreras, G. (2008). Las concepciones que orientan las prácticas evaluativas de los profesores: un problema a develar. Estudios Pedagógicos, 34(2), 245-262. http://dx.doi.org/10.4067/S0718-0705200800020 0015

Reisigl, M. \& Wodak, R. (2001). Discourse and discrimination: Rhetorics of racism and antisemitism. Routledge.

Reisigl, M. \& Wodak, R. (2016). The Discourse-Historical Approach (DHA). In R. Wodak \& M. Meyer (Eds.), Methods of Critical Discourse Analysis (pp. 23-61). SAGE Publications.

Rodríguez, C. \& Jarpa, C. G. (2015). Capacidad predictiva de las notas en enseñanza media sobre el rendimiento en pruebas de selección universitaria: el caso chileno. Aula Abierta, 43(2), 61-68. http://dx.doi.org/10.1016/j.aul a.2015.03.002

Rogers, R., Schaenen, I., Schott, C., O’Brien, K., Trigos-Carrillo, L., Starkey, T. \& Carter Chasteen, C. (2016). Critical Discourse Analysis in Education: A review of the literature, 2004 to 2012. Review of Educational Research, 86(4), 1192-1226. https://doi.org/10.3102/0034654316628993

Rokita-Jaśkow, J. \& Ellis, M. (Eds.) (2019). Early Instructed Second Language Acquisition: Pathways to Competence. Multilingual Matters.

Rubin, D. I. \& Kazanjian, C. J. (2011). "Just another brick in the wall": Standardization and the devaluing of education. Journal of Curriculum and Instruction (JoCI), 5(2), 94-108. https://doi.org/10.3776/joci.2011.v5n2p94-108

Sepúlveda, P. (2018). Liceo Manuel de Salas elimina las notas y alarga 15 minutos los recreos. La Tercera. https://b it.ly/2CX7Sj0

Silbaugh, K. B. (2011). Testing as Commodification. Washington University Journal of Law and Policy, 35(1), 309336. https://openscholarship.wustl.edu/law_journal_law_policy/vol35/iss1/15/

Stake, R. E. (2005). Qualitative case studies. In N. K. Denzin \& Y. S. Lincoln (Eds.), The Sage handbook of Qualitative Research ( $3^{\text {rd }}$ ed. pp. 443-466). Sage.

Van Dijk, T. (2015). Critical Discourse Analysis. In D. Tannen, H. Hamilton \& D. Schiffrin (Eds.), The handbook of Discourse Analysis (pp. 466-485). Wiley-Blackwell.

Warriner, D. (2016). 'Here, without English, you are dead': Ideologies of language and discourses of neoliberalism in adult English language learning. Journal of Multilingual and Multicultural Development, 37(5), 1-14. https:// doi.org/10.1080/01434632.2015.1071827

White, C. B. \& Fantone, J. C. (2010). Pass-fail grading: Laying the foundation for self-regulated learning. Advances in Health Sciences Education, 15(4), 469-477. https://doi.org/10.1007/s10459-009-9211-1

Wilkins, A. (2013). Neoliberalism, pedagogy and the curriculum. Journal of Pedagogy, 4(1), 5-10. https://sciendo.c om/issue/JPED/4/1

Wodak, R. \& Meyer, M. (2016). Methods of Critical Discourse Studies. Routledge.

Wright, C. (2012). Educational Orientation and Upward Influence: An Examination of Students' Conversations about Disappointing Grades. Communication Education, 61(3), 271-289. https://doi.org/10.1080/03634523 .2012 .671949

Xiong, T. \& Yuan, Z. (2018). "It was because I could speak English that I got the job": Neoliberal discourse in a Chinese English Textbook Series. Journal of Language, Identity \& Education, 17(2), 103-117. https://doi.org/10.1080 /15348458.2017.1407655 
Carolina Pérez-Arredondo, et al. Parent and Teacher Perceptions of Gradeless Assessment and its Re...

Zappettini, F. (2014). 'A badge of Europeanness': Shaping identity through the European Union's institutional discourse on multilingualism. Journal of Language and Politics, 13(3), 375-402. https://doi.org/10.1075/jlp.1 3.3.01zap

\section{Notes}

[1] The acronym stands for Prueba de Selección Universitaria, standardized test to access higher education which measures students' knowledge on Language and Mathematics, plus one of the following subjects: Sciences (Physics, Biology and Chemistry) or History and Geography.

[2] According to Guskey and Marzano, a rubric refers to any "scoring tools containing criteria and a performance scale that allows us to define and describe the most important components that comprise complex performances and products" (2001, p. 8; emphasis in original).

[3] The interviews and focus group protocols can be found in the following link: shorturl.at/vDR18

\section{INFORMACIÓN ADICIONAL}

Cómo citar: Pérez-Arredondo, C. y Bernales-Carrasco, A. (2022). Parent and Teacher Perceptions of Gradeless Assessment and its Relationship with Education Commodification: A Case Study. Revista Educación, 46(1). http://doi.org/10.15517/revedu.v46i1.45575 